\title{
Vertical mixing as a determinant of trophic status in deep lakes: a case study from two lakes south of the Alps (Lake Garda and Lake Iseo)
}

\author{
Nico SALMASO*, Rosario MOSELLO ${ }^{1) *}$, Letizia GARIBALDI ${ }^{2}$, Fabio DECET $^{3)}$, Maria Cristina BRIZZIO ${ }^{1)}$ and \\ Paolo CORDELLA
}

Dipartimento di Biologia, Università di Padova, Via U. Bassi 58/B, I-35131 Padova, Italy

${ }^{1)}$ C.N.R. Istituto per lo Studio degli Ecosistemi, L.go Tonolli 50, I-28922 Verbania Pallanza, Italy

${ }^{2}$ Dipartimento Scienze Ambiente e Territorio, Università di Milano, Via Emanueli 15, 20126 Milano, Italy

${ }^{3)}$ ARPAV, Dipartimento di Belluno, Via S. Andrea 1, 32100 Belluno, Italy

*e-mail corresponding authors: nico.salmaso@unipd.it; r.mosello@ise.cnr.it

\begin{abstract}
The identification of the factors and mechanisms determining a particular lake's typology is crucial for the correct interpretation of trophic evolution. Nutrient concentrations are not the only properties which determine the trophic characteristics of lakes; others, such as morphometry, hydrology and climatic conditions, also have a major influence on the development of algal biomass and species composition. Large, deep lakes belong to a well defined typology. Their trophic status depends not only on algal nutrient loads, but also on the extent of the spring vertical mixing and renewal time. These factors are closely interrelated, for the actual renewal time approaches the theoretical renewal time only during the complete overturn. This paper compares the influence of different circulation patterns on the trophic status of two deep subalpine lakes with contrasting mixing characteristics. Lake Garda is the largest lake in Italy $\left(S=368 \mathrm{~km}^{2}, V=49 \mathrm{~km}^{3}, Z_{\max }=350 \mathrm{~m}\right)$. It is characterised by irregular circulation events (oligomixis); during the 1990s, complete homogenisation of the water column occurred in 1991 and 1999-2000. The years between these episodes showed an increase of hypolimnetic temperatures and a progressive vertical stratification of nutrients. Full overturn episodes were characterised by a sudden decrease of temperature and complete homogenisation of the chemical and physical variables along the water column, with a corresponding increase of nutrients and algal biomasses at the surface. In contrast, the last mixing involving the deepest waters in Lake Iseo $\left(S=60,9 \mathrm{~km}^{2}, V=7,6 \mathrm{~km}^{3}, Z_{\max }=251 \mathrm{~m}\right)$ occurred at the beginning of the $1980 \mathrm{~s}$, after which the reduced water renewal and the high trophic level resulted in a marked decrease in oxygen concentrations and in the establishment of conditions of anoxia during the 1990s. At present the lake is meromictic. In 1999 and 2000, when a complete overturn was observed in lakes Maggiore and Como as well as in Lake Garda, Lake Iseo experienced a spring mixing which was still limited, but able to determine an increase in the algal biomass.
\end{abstract}

Key words: vertical mixing, trophic evolution, Lake Garda, Lake Iseo, deep lakes, renewal time

\section{INTRODUCTION}

Vertical water mixing in lakes in temperate climates has its maximum extension between the end of winter and the beginning of spring. In this period the difference in temperature between the surface and the bottom reaches minimum annual values. The deep lakes located south of the Alps (from E to W: Garda, Iseo, Como, Lugano and Maggiore) should be classified as warm monomictic. Lakes in this category circulate completely once a year in the winter at or above $4{ }^{\circ} \mathrm{C}$ and are stably stratified for the remainder of the year (Hutchinson 1957; Wetzel 2001). However, owing to the great depth of the deep southern subalpine lakes - ranging from 251 $\mathrm{m}$ (Iseo) to $410 \mathrm{~m}$ (Como) - they are typically characterised by variable temporal periods of incomplete mixing, interspersed with occasional events of complete mixing during cold, windy winters. This situation, which is known as oligomixis, clashes with that of lakes which circulate freely every year (holomictic lakes) or show a constant stratification (meromictic lakes) (Wetzel 2001).
In deep lakes, vertical mixing is an important factor in determining the annual evolution of the physical and chemical characteristics along the water column, and in controlling the development of the algal biomass in the upper layers. More specifically, in oligomictic lakes the chemical characteristics of the deep hypolimnion not involved in the spring mixing are determined both by the mineralization of organic matter and by the duration of their temporal isolation from the surface waters (Salmaso \& Decet 1998). On the other hand, the extent of the vertical mixing has important consequences for the fraction of algal nutrients that may be recycled annually from the deep layers to the surface. Trophic status in deep oligomictic lakes depends not only on algal nutrient loads, but also on the extent of the spring vertical mixing and renewal time. These factors are closely interrelated, for the actual renewal time approaches the theoretical renewal time (estimated from the volume of the lake divided by that of the outflow) only during the complete overturn and homogenisation of the water column (holomixis).

The aim of this paper is to compare the influence of different circulation patterns on the trophic status of two 

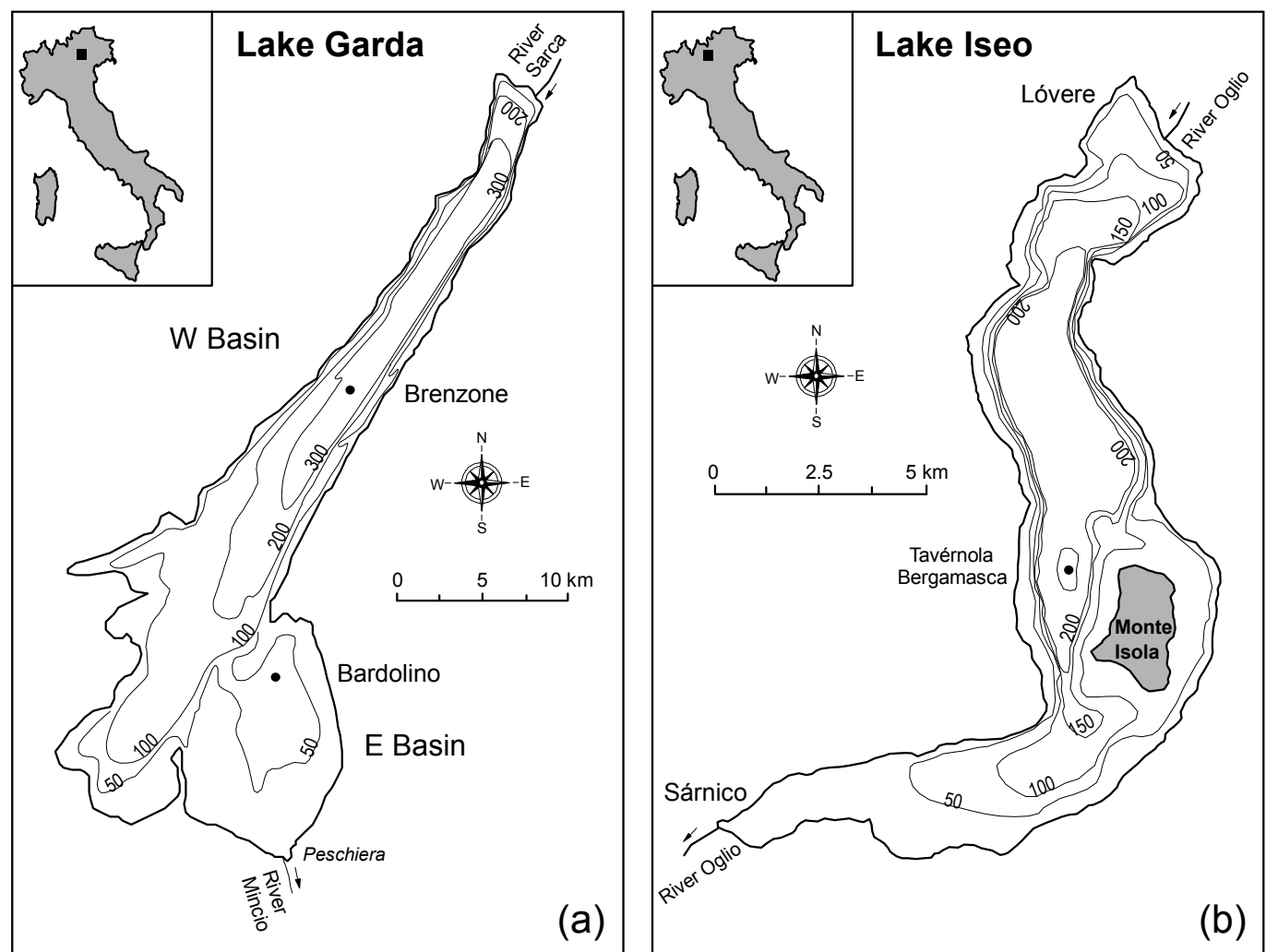

Fig. 1. Bathymetric map of (a) Lake Garda and (b) Lake Iseo. The location of the sampling stations is indicated by filled circles.

Tab. 1. Main morphometric and hydrological characteristics of Lake Garda and Lake Iseo. (a): 1951-1987; (b): 1951-1996.

\begin{tabular}{lcc}
\hline & Lake Garda & Lake Iseo \\
\hline Lake height $\left(\mathrm{m}^{2}\right.$ a.s.l. $)$ & 65 & 185 \\
Lake area $\left(\mathrm{km}^{2}\right)$ & 368 & 61 \\
Lake volume $\left(\mathrm{km}^{3}\right)$ & 49 & 7.6 \\
Maximum depth $(\mathrm{m})$ & 350 & 251 \\
Mean depth $(\mathrm{m})$ & 133 & 124 \\
Outflow $\left(\mathrm{m}^{3} \mathrm{~s}^{-1}\right)$ & $58(\mathrm{a})$ & $57.5(\mathrm{~b})$ \\
Theoretical water renewal time $(\mathrm{y})$ & 27 & 4.2 \\
Watershed area (lake included) $\left(\mathrm{km}^{2}\right)$ & 2260 & 1842 \\
\hline
\end{tabular}

deep subalpine lakes (Garda and Iseo) with contrasting mixing characteristics. Lake Garda is a typical oligomictic lake, for which the most recent complete mixing events were documented in 1991 and in the biennium 2000-2001 (Salmaso et al. 2001a). In contrast, the last complete circulation in Lake Iseo was observed at the beginning of the $1980 \mathrm{~s}$, after which the reduced water renewal, associated with deteriorating trophic conditions, resulted in a marked decrease in hypolimnetic oxygen concentrations and in the establishment of conditions of anoxia during the 1990s (Garibaldi et al. 1999).

\section{STUDY SITES}

Lake Garda is the largest Italian lake, with a volume of $49 \mathrm{~km}^{3}$, a surface of $368 \mathrm{~km}^{2}$ and a maximum depth of $350 \mathrm{~m}$ (Fig. 1a; Tab. 1). The main inflow is the River
Sarca, at the northern edge of the lake; other tributaries are less important and mainly flow towards the western and northern shores. The outflow, with an average discharge of $58 \mathrm{~m}^{3} \mathrm{~s}^{-1}$, is the River Mincio, at the southern edge of the lake. Compared with the other deep southern subalpine lakes, Lake Garda is characterised by a long theoretical water renewal time ( 27 years), due to its low catchment (lake included)/lake surface ratio (around 6) and to low annual rainfall (790-1150 mm, IRSA 1974). Details of the catchment and the lake are reported in IRSA (1974).

Lake Iseo is the fourth largest Italian lake, after Garda, Maggiore and Como. It has a surface of $61 \mathrm{~km}^{2}$, a volume of $7.6 \mathrm{~km}^{3}$ and a maximum depth of $251 \mathrm{~m}$ (Fig. 1b; Tab. 1). The inflow and outflow is the River Oglio. At the centre of the lake is the island of Monte Isola, which is one of the largest $\left(4 \mathrm{~km}^{2}\right)$ and highest (414 
$\mathrm{m}$ above the lake surface) island in Europe. The theoretical water renewal time is about 4.2 years (Garibaldi et al. 1999).

\section{METHODS}

Samples were collected from Lake Garda normally every four weeks between 1991 and 2001 in the deepest zone of the lake (west basin, off Brenzone) and in the shallower east basin (off Bardolino; Fig. 1a) by the University of Padova, in cooperation with the ARPAV (Veneto Region Environment Protection Agency), Districts of Verona and Belluno. Except where otherwise stated, the data in this paper refer to the samples collected at the Brenzone station. On each sampling, measurements of temperature, $\mathrm{pH}$, conductivity and oxygen were carried out on the water column using underwater multiparameter probes. Detailed chemical analyses have been performed since 1995-1996. Water samples for chemical analysis were collected at $0.5,20,60,100,150,200$ and $300 \mathrm{~m}$; further samples for oxygen determination (Winkler method) were collected at $10 \mathrm{~m}, 250 \mathrm{~m}$ and around $1 \mathrm{~m}$ above the bottom. In this paper, the total phosphorus (TP) concentrations refer to the analyses carried out on the samples collected monthly from January 1996 to December 2000 and from August to December 2001; these data have been integrated with the analyses carried out by the CNR-ISE on the samples collected at Brenzone in March 2001. Water samples for chlorophyll a (Lorenzen 1967) and phytoplankton analyses were collected within the euphotic layer (0-20 m) from June 1992; prior to this the analyses were carried out on integrated samples collected at the surface. Details of sampling procedures, field measurements, chemical methods, chlorophyll- $a$ and phytoplankton analyses were reported by Salmaso et al. (1997).

Lake Iseo was sampled from 1993 by the University of Milan in the deepest zone of the lake, off Tavérnola Bergamasca (Fig. 1b). In 1993 and from 1998 to 2001 sampling was performed monthly, less frequently from 1994 to 1997 (to a total of 4-8 sampling dates). Water samples for chemical analysis were collected at $0,1,3$, $5,10,20,30,50,75,100,150,200 \mathrm{~m}$ and at the bottom. Detailed information on the development of the algal biomass in the layer $0-10 \mathrm{~m}$ has been available since 1998 (Garibaldi et al. 2003). The methods used for measuring the physical, chemical and biological variables are reported in Garibaldi et al. (1997). Since the 1960 s, the temporal series of oxygen in the deepest zone of Lake Iseo were recorded by the CNR-ISE in the period from March to April (Mosello et al. 1997).

The concentrations of total phosphorus and dissolved oxygen in the layers $0-100 \mathrm{~m}, 100-200 \mathrm{~m}$ and $200 \mathrm{~m}$-bottom have been computed using lake volume weighted averages.

The chemical methods were checked and verified in the framework of the projects AQUACON-MedBas (Mosello et al. 1995) and QuAlps (Mosello \& Salmaso
2000). Direct comparisons carried out yearly among the research groups involved in this work showed good agreement in the results of the chemical analyses.

\section{RESULTS AND DISCUSSION}

\subsection{Effects of oligomixis and meromixis on the vertical distribution of oxygen and phosphorus concentrations}

Figure 2a shows the temporal evolution of the vertical distribution of dissolved oxygen recorded in the deepest zone of Lake Garda between 1996 and 2001. During this period, average concentrations in the deep hypolimnion (200 m-bottom) were always greater than $6 \mathrm{mg} \mathrm{l}^{-1}$, indicating a satisfactory level of oxygenation. However, from 1996 to 1998, and during 2001, the water column was characterised by the presence of marked concentration gradients, while in the biennium 1999-2000 oxygen was evenly distributed along the water column during the spring overturn. These contrasting situations were the result of an incomplete cooling and consequent partial overturn of the water column from 1996 to 1998 and in 2001, and by a complete cooling and complete circulation of the lake in the spring of 1999 and 2000; see Salmaso et al. (2001a; 2001b) for details on the thermal structure of Lake Garda. In this context the term "circulation" does not necessarily imply the intervention of a single mixing mechanism. In deep lakes, a complete overturn may be triggered by convective motions (originating in the winter cooling of the water masses), but also by water currents driven by strong winds along the thalweg of the lake and by the deep flux of colder water from the tributaries (Ambrosetti et al. 1983).

The physical and chemical profiles allowed to estimate in some detail the temporal evolution of the maximum mixing depth reached in spring. During the last decade, full spring overturn episodes, with a complete homogenisation of the chemical and physical characteristics of the water column, were observed in 1991 as well as in 1999 and 2000. In contrast, from 1992 to 1998 and in 2001 the mixing depth during the maximum spring overturn ranged from 140 to $200 \mathrm{~m}$; the three years of complete circulation were characterised by a marked cooling of the whole water column, as a result of the cold, harsh winters which occurred between 1990 and 1991, 1998 and 1999, and 1999 and 2000. In particular, the water column in these three years experienced its greatest cooling after a decrease in the mean winter (December-February) air temperatures of around $2{ }^{\circ} \mathrm{C}$ compared to previous years (Salmaso et al. 2001b). At present, the periods of partial mixing appear to be strictly determined by the evolution of the climate. The increase of the ionic content in the deep hypolimnion (essentially due to $\mathrm{Ca}^{2+}$ and alkalinity) was secondary to temperature as a factor controlling water density gradients during the years of incomplete overturn (Salmaso \& Decet 1998). 

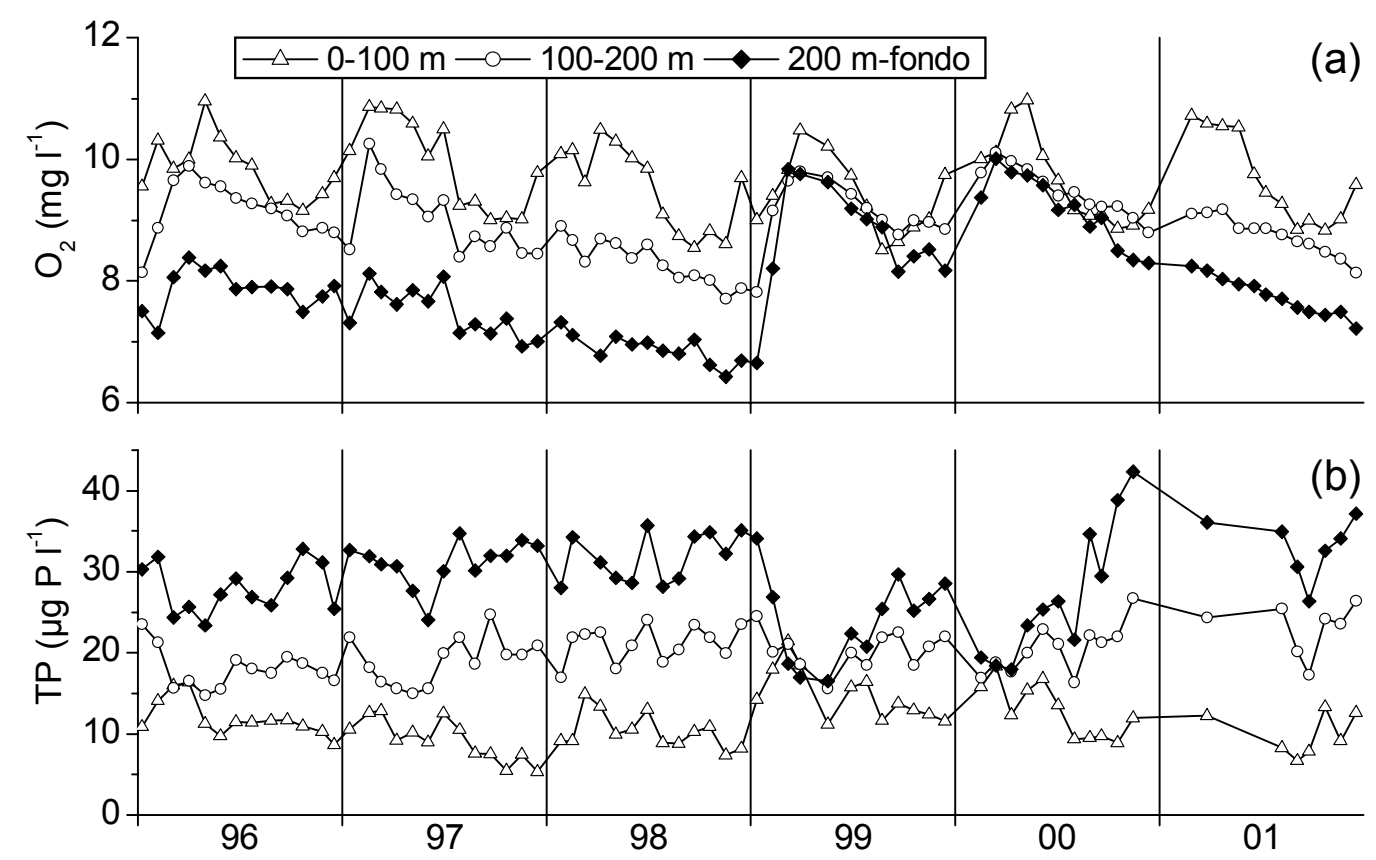

Fig. 2. Temporal variations of (a) dissolved oxygen and (b) total phosphorus in Lake Garda from 1996 to 2001.

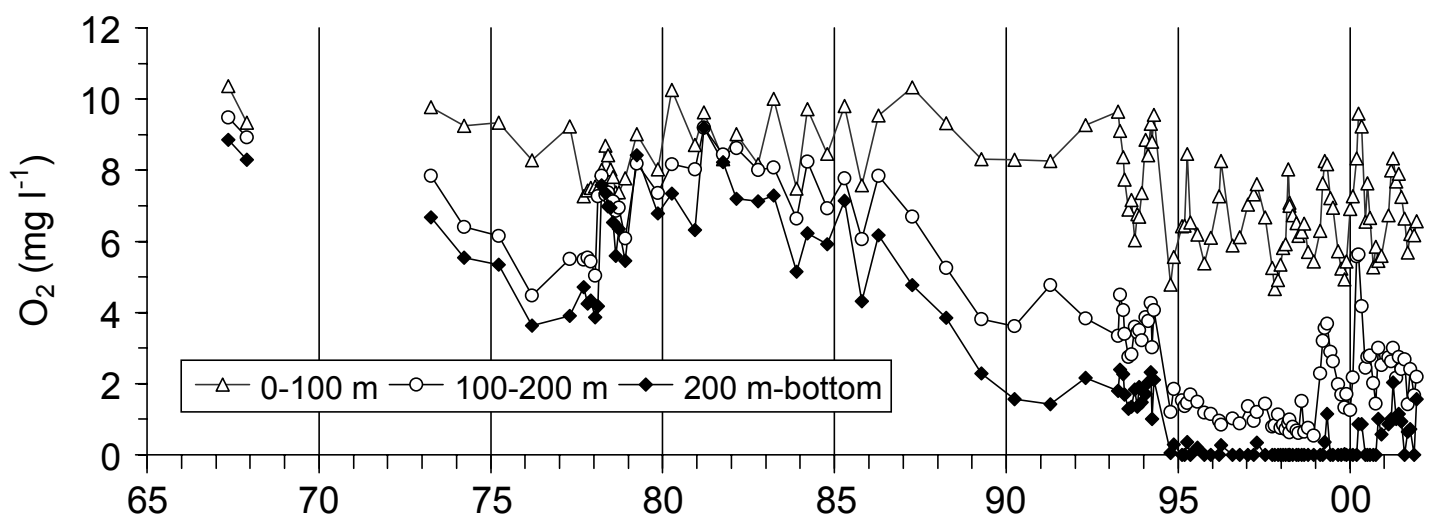

Fig. 3. Temporal variations of dissolved oxygen in Lake Iseo from the 1960s to December 2001.

Oligomixis in Lake Garda has a major effect on the vertical distribution of algal nutrients and, consequently, on their supply in the superficial, euphotic layers. In years of incomplete mixing, the concentrations of TP in the layer from $100 \mathrm{~m}$ to the bottom were 2-3 times as high as those measured in the layer $0-100 \mathrm{~m}$ (Fig. 2b). In contrast, during years when there was a complete overturn, TP concentrations assumed homogeneous values in the whole water column in spring, reaching their maximum values in the euphotic zone (over $20 \mu \mathrm{g} \mathrm{P}^{-1}$ in 1999 in the layer from 0 to $20 \mathrm{~m}$ ) and constituting an important source of nutrients for algal growth in the whole basin during the spring and summer months (section 4.2).
The temporal evolution of the vertical distribution of dissolved oxygen concentrations in the deepest zone of Lake Iseo from the second half of the 1960 s to 2001 is illustrated in figure 3 . These 30 years were characterised by two contrasting situations. From the mid 1960s to the mid 1980s, periods of partial overturn alternated with complete circulation episodes, so that Lake Iseo could be ascribed to the category of oligomictic lakes, as Lake Garda is now. The last circulation of Lake Iseo was documented in 1981 (Mosello 1983; Garibaldi et al. 1995). Successively, starting from the mid 1980s, there was a progressive, stable separation of the deep waters from the surface layers. In particular (Fig. 4a), the layer between $200 \mathrm{~m}$ and the bottom was in an anoxic condi- 

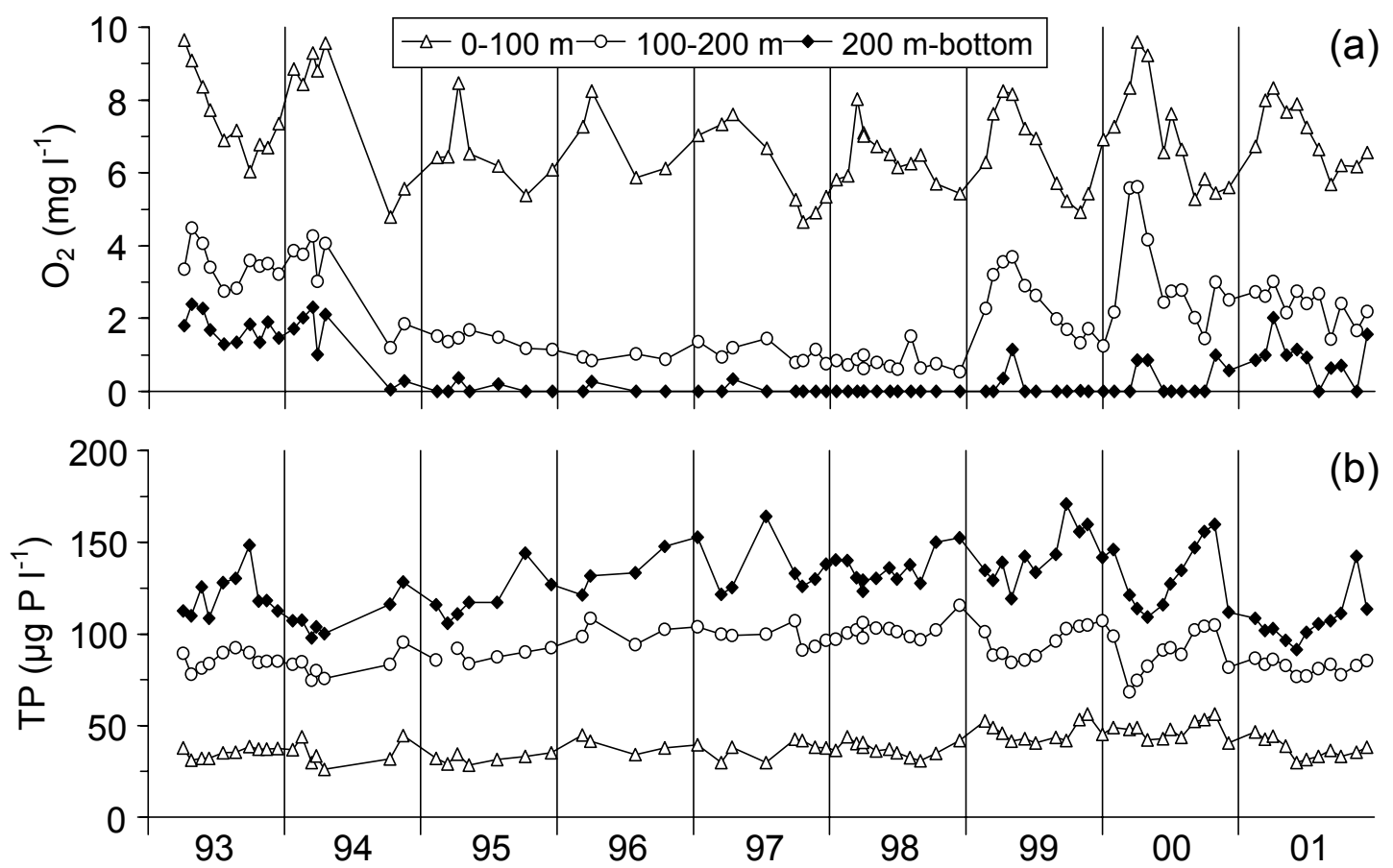

Fig. 4. Temporal variations of (a) dissolved oxygen and (b) total phosphorus in Lake Iseo from 1993 to 2001.

tion between the end of 1994 and 1998; at the same time, oxygen concentrations in the layer between 100 $200 \mathrm{~m}$ were very low $\left(<2 \mathrm{mg} \mathrm{l}^{-1}\right)$. Contrary to this trend, a significant supply of oxygen, due to a major cooling of the water column (Brizzio et al. 2001), which determined a major spring water renewal, was observed in the water masses between 100-200 $\mathrm{m}$ in 1999 and 2000 . In this biennium, and in the following year, the deepest layer $(<200 \mathrm{~m})$ underwent moderate oxygenation, reaching a concentration of around $2 \mathrm{mg} \mathrm{l}^{-1}$. It will be recalled that during 1999 and 2000 Lake Garda underwent a complete spring circulation, as a consequence of the occurrence of two harsh winters. The spring vertical mixing in Lake Iseo in these two years - as deduced from an analysis of the physical and chemical profiles extended to a depth apparently between $100 \mathrm{~m}$ and 200 $\mathrm{m}$. The years immediately before and after this biennium appeared to be characterised by a more limited mixing extension (estimated between 50 and $100 \mathrm{~m}$ in 1998 and 2001).

The greater extent of vertical mixing in 1999 and 2000 was also paralleled by a greater replenishment of phosphorus from the deep hypolimnion towards the superficial layers (Fig. 4b); in these two years the annual average values of TP in the layer $0-100 \mathrm{~m}$ were 47 and $48 \mu \mathrm{g} \mathrm{P}{ }^{-1}$, respectively, whereas the corresponding values from 1993 to 1998 and in 2001 were 36 and 37 $\mu \mathrm{g} \mathrm{P}{ }^{-1}$, respectively. These values may be considered very high. However, as we will show in the next section (4.2), the greater availability of phosphorus during 1999-2000 had important consequences for the development of algal biomass.
The incomplete overturn of Lake Iseo during the last 20 years was favoured by an increase in the density of the deep waters due to a rise in concentrations of calcium and bicarbonate ions (Garibaldi et al. 2000; Brizzio et al. 2001). In 1998 and 1999, for example, the concentrations of $\mathrm{Ca}^{2+}$ in the layers from 0 to $200 \mathrm{~m}$ at spring overturn were equal to 2202 and 2282 meq 1$^{-1}$, respectively; in the layer from $200 \mathrm{~m}$ to the bottom these concentrations raised to 2370 and $2491 \mathrm{meq} \mathrm{l}^{-1}$, respectively. Similar differences were found for $\mathrm{HCO}_{3}{ }^{-}$, whereas the other ions showed only little or no vertical concentration gradients (Brizzio et al. 2001). When there is an incomplete overturn, the renewal time of the hypolimnetic waters is low, favouring an increase in algal nutrients (P-, N- and Si-compounds) as well as (in calcareous lakes) dissolution of $\mathrm{CaCO}_{3}$ from settling particles, with a corresponding increase in water density. The formation of calcite particles in the epilimnion is a function of algal activity (which depletes $\mathrm{CO}_{2}$ and increases $\mathrm{pH}$ ) and, eventually, of the trophic status of a lake. If conditions favouring incomplete mixing prevail (e.g. warm winters, excessive nutrient loads), a spiral effect is set off, which determines a pronounced separation of the lake water into two strata, with very different renewal times (meromixis).

\subsection{Effects of the overturn on the recent trophic evolution of lakes Garda and Iseo}

Information on the temporal evolution of nutrients and algal biomass in the two lakes is available for the period from 1998 to 2001. Figures 5a-b show the temporal evolution of the maximum concentrations of TP at 
Total phosphorus $\left(\mu \mathrm{g} \mathrm{PI^{-1 } )}\right.$
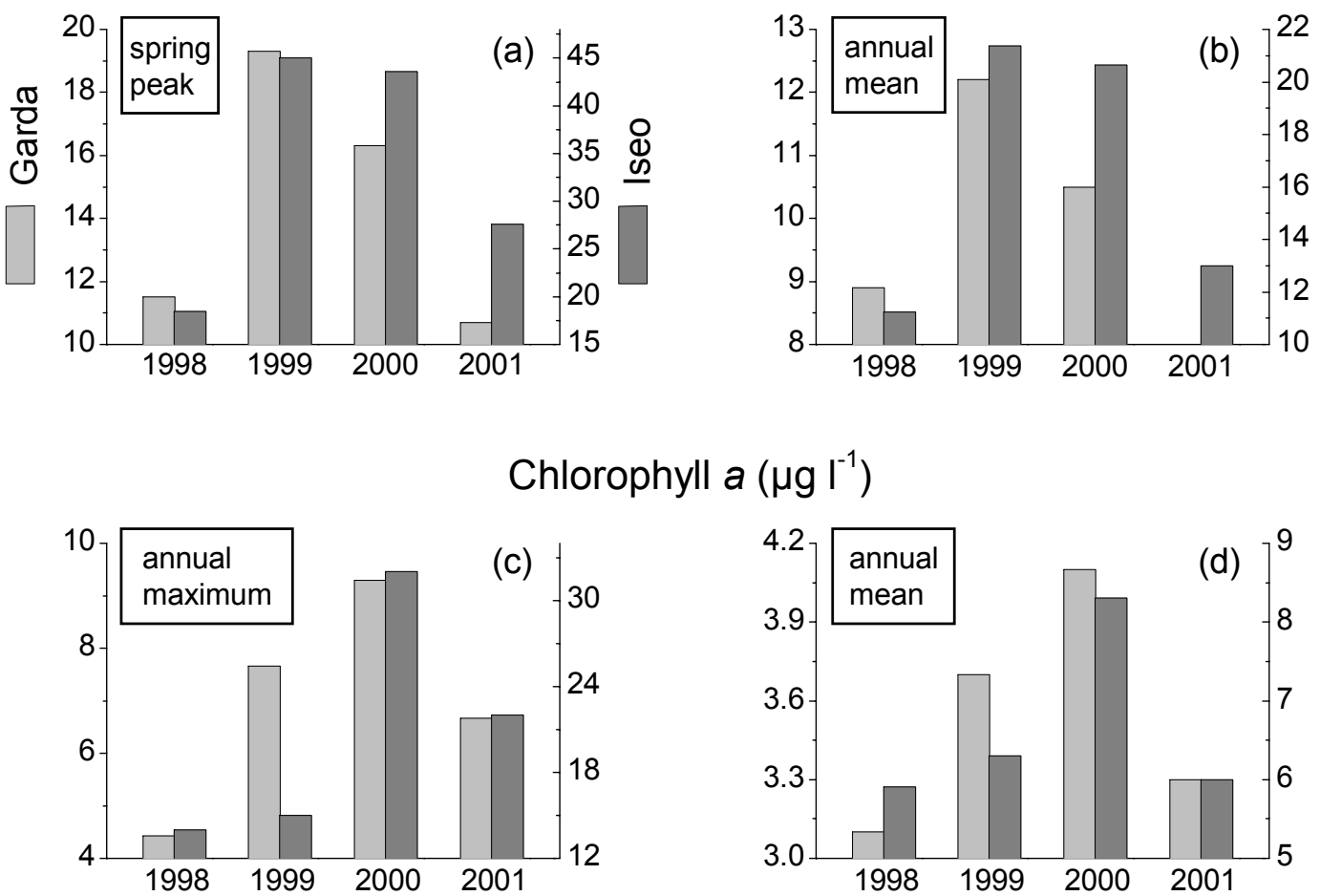

Chlorophyll a $\left(\mu \mathrm{g} \mathrm{I}^{-1}\right)$

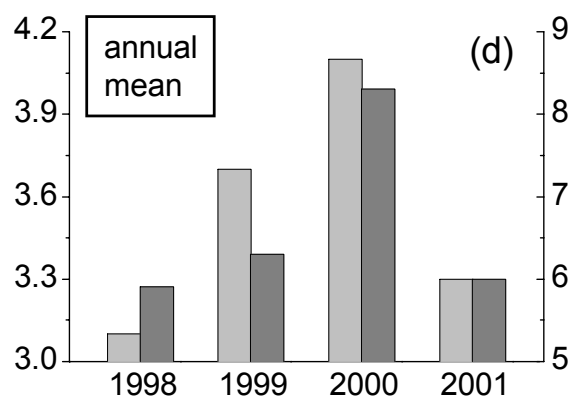

Fig. 5. Temporal evolution of some descriptors of trophic status in lakes Garda and Iseo from 1998 to 2001. The legend and the order of the axes are given in panel (a). (Explanations in the text).

spring overturn and the annual average values of TP in the surface layer $(0-20 \mathrm{~m})$. In figure $5 \mathrm{a}$ the values of TP at spring overturn were estimated by averaging the values for the two consecutive months - between February and April - characterised by the highest concentrations. Figures $5 \mathrm{c}-\mathrm{d}$ illustrate the temporal evolution of the maximum and mean annual concentrations of chlorophyll- $a$ in the layers $0-20 \mathrm{~m}$ (Garda) and $0-10 \mathrm{~m}$ (Iseo). The detailed seasonal evolution of the chlorophyll- $a$ and phytoplankton in these two lakes was recently examined by Salmaso (2002) and Garibaldi et al. (2003).

The variables considered in figure 5 are characterised by different ranges and absolute values, indicative of two lakes with different trophic levels. The values computed for Lake Garda and Lake Iseo indicate that the former is in a condition between oligotrophy and mesotrophy, and the latter between mesotrophy and eutrophy (OECD, 1982). These classifications are confirmed also considering the annual averages and minimum values of transparency (Salmaso 2002; Garibaldi et al. 2003).

Nevertheless, in spite of the very different absolute values recorded in the two basins, the temporal evolution of the variables in figure 5 are characterised by a strict temporal correlation, which originated from a corresponding synchronism in the interannual variations in the extent of the spring vertical mixing. After all, this synchronicity was determined by the common effects caused by climatic evolution in the southern subalpine area (Maugeri \& Mazzucchelli 2002; Brunetti et al. 2000; Giugliacci et al. 2001). In particular, the increase in phosphorus concentrations and chlorophyll- $a$ in the productive layers during 1999 and 2000 was due to the complete overturn of the water column in Lake Garda and to a larger extent of the mixed layer in Lake Iseo, after the occurrence of two cold, harsh winters.

An estimate of the contribution of the spring epilimnetic phosphorus deriving from mixing processes is given in table 2 . The increases in the 0-20 m layer were obtained by considering the differences in the TP content before the beginning of the deep mixing processes (between November and December) and during the maximum extent of vertical mixing (between February and March). Only approximate values can be obtained in this way, because the variations in the P-content in the epilimnetic layers also originated from the contribution of nutrients from rivers and other inflowing water, and from their loss via the outflow and particulate sedimentation. In 1998 and 2001, during a limited overturn, the input of nutrients to the productive layers in lakes Garda and Iseo was below $40 \mathrm{t}$ and $10 \mathrm{t}$, respectively; in 1999 and 2000, during the greatest extension of the overturn, these values were 80 and $44 \mathrm{t}$ (Garda), and 29 and $26 \mathrm{t}$ (Iseo), respectively (Tab. 2). Even considering the limiting assumptions used in the computations, the estimated epilimnetic supply of TP during the spring months constitutes a high, rapid and temporally delim- 
Tab. 2. Estimates of the replenishment of phosphorus to the epilimnetic $(0-20 \mathrm{~m})$ layers during spring overturn. BM: before spring mixing; SM: spring mixing; ${ }^{(a)}$ : computations carried out for the whole lake, including the results collected at Bardolino (Fig. 1a); ${ }^{(b)}$ : computations include only the station of Brenzone. (Explanations in the text).

\begin{tabular}{|c|c|c|c|c|c|c|c|}
\hline & & \multicolumn{3}{|c|}{ Lake Garda $^{(\mathrm{a})}$} & \multicolumn{3}{|c|}{ Lake Iseo } \\
\hline & & $\begin{array}{l}\text { TP conc. } \\
\left(\mu \mathrm{g} \mathrm{P}^{-1}\right)\end{array}$ & $\begin{array}{l}\text { TP content } \\
\text { (t) }\end{array}$ & $\begin{array}{c}\text { TP increase } \\
(\mathrm{t})\end{array}$ & $\begin{array}{l}\text { TP conc. } \\
\left(\mu \mathrm{g} \mathrm{P}^{-1}\right)\end{array}$ & $\begin{array}{l}\text { TP content } \\
\text { (t) }\end{array}$ & $\begin{array}{c}\text { TP increase } \\
\text { (t) }\end{array}$ \\
\hline \multirow[t]{2}{*}{1998} & $\mathrm{BM}$ & 6 & 37 & & 9 & 7 & \\
\hline & SM & 12 & 77 & 39 & 22 & 17 & 9 \\
\hline \multirow[t]{2}{*}{1999} & $\mathrm{BM}$ & 7 & 42 & & 8 & 6 & \\
\hline & SM & 19 & 122 & 80 & 46 & 35 & 29 \\
\hline \multirow[t]{2}{*}{2000} & $\mathrm{BM}$ & 10 & 65 & & 11 & 8 & \\
\hline & SM & 17 & 109 & 44 & 45 & 34 & 26 \\
\hline \multirow[t]{2}{*}{2001} & $\mathrm{BM}$ & 10 & 62 & & 14 & 11 & \\
\hline & SM & 11 & 72 & $10^{(\mathrm{b})}$ & 27 & 21 & 10 \\
\hline
\end{tabular}

ited input of nutrients, readily utilisable for phytoplankton growth. The importance of this supply is highlighted when we consider that, on an annual basis, the external total loads of TP in the two lakes were estimated at around 170-200 $\mathrm{t} \mathrm{y}^{-1}$ (Garda: Decet \& Salmaso 1997; Salmaso et al. 1997) and 80-90 t y ${ }^{-1}$ (Iseo: Garibaldi et al. 1998; 1999).

The analysis of the whole set of data available on Lake Garda since 1991 clearly demonstrates the importance of the spring circulation in fertilising epilimnetic waters in deep lakes. The results show that the lake volumes involved at spring overturn have a significant impact on the trophic variables, with positive effects on epilimnetic phosphorus, chlorophyll- $a$, total algal biovolumes and cyanobacteria, and negative effects on water transparency (Salmaso et al. 2001a; 2002). Consequently, the trophic status in the 1990s oscillated between oligo-mesotrophy and mesotrophy. The parallel comparison between the temporal evolution of the spring mixing depth and the principal trophic variables in lakes Garda and Iseo suggests that climatic evolution plays a significant role in controlling, on a regional scale, the interannual variations in trophic status in deep lakes.

The functioning mechanisms for a particular lake typology are comparable. In particular, the pool of factors controlling the long-term evolution of the trophic characteristics of lakes Garda and Iseo are the same as those affecting deep lakes, including the southern subalpine lakes. These factors include nutrient concentrations (P$\mathrm{N}$ - loads), water renewal and mixing depth. However, these factors may have a different relative importance in different lakes. The high water renewal rate of Lake Iseo suggests that occasional direct fertilisation events from the rivers are potentially of major importance (cf. Garibaldi et al. 1999). In contrast, in Lake Garda, the low water supply from rivers, practically only from the northern River Sarca (Fig. 1; Decet \& Salmaso 1997), means that the spring replenishment from the deep hypolimnion constitutes a significant input of recycled nutrients to the productive layers of the entire lake every year. With the progressive formation of a stable and isolated epilimnion, nutrients originating in the catch- ment or from the deep hypolimnion have less importance than in the coldest months (Salmaso \& Decet 1998).

\section{CONCLUSIONS}

As stated by Goldman \& Jassby (1990), despite the acknowledged importance of spring mixing events as a cause of interannual variation of algal production in lakes, their quantitative significance has been poorly investigated. The research carried out on lakes Garda and Iseo confirmed the importance of the extent of the overturn in controlling the fraction of algal nutrients recycled from the deepest waters to the productive layers in deep lakes. In particular, recent investigations (19982001) revealed the existence of a temporal correspondence in the interannual variations in the extent of the spring vertical mixing in lakes Garda and Iseo. This temporal synchronism derives from the common effects of the winter evolution of climatic conditions on the subalpine region, which results in a positive association in the temporal evolution of the trophic characteristics of the two lakes. During 1999 and 2000, following two cold, harsh winters, the productive layers of lakes Garda and Iseo underwent a major fertilisation, which was reflected in a corresponding increase of chlorophyll- $a$.

The above results make it essential to reconsider the significance of the concept of trophic category (sensu OECD, 1982) used for deep lakes. In this classification of water bodies a distinction must be made between potential trophic status and apparent (observed) trophic status (Fig. 6). In the first case the trophic status is determined by the overall content of nutrients in the lake, irrespective of their distribution along the water column, whereas in the second case the term refers to the actual quantity of nutrients available in the productive layers for algal growth. Depending on the influence of rivers, the apparent trophic status may be affected, besides the hypolimnetic P-supply and vertical mixing (paths 1 and 2 in Fig. 6a), by the epilimnetic input of nutrients (path 3 in Fig. 6a). In oligomictic and meromictic lakes the effects of vertical mixing on the trophic status will be a function of the intensity of the overturn and of the hypolimnetic stock of nutrients. 
(a)

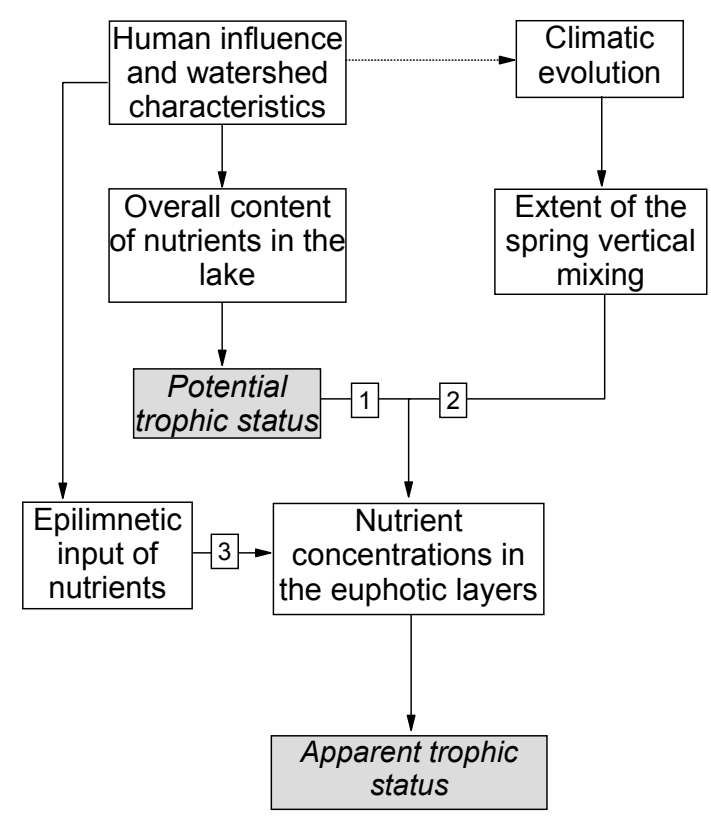

(b)

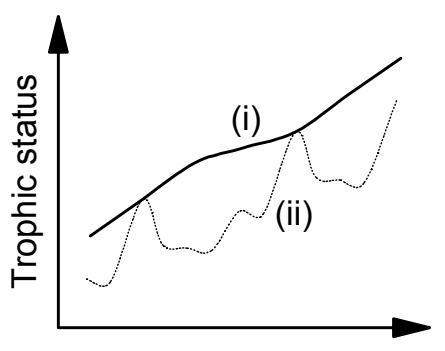

(c)

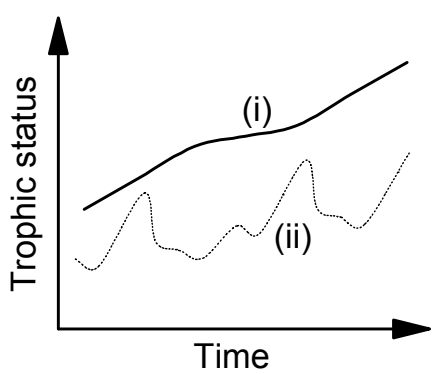

Fig. 6. (a) Principal factors influencing trophic status in deep lakes and temporal variations in apparent (ii) and potential (i) trophic status in (b) oligomictic and (c) meromictic lakes. The two examples in (b) and (c) assume the existence of a progressive increase in trophic status.

The extent of the spring water mixing helps to explain the interannual variations of productivity below a potential trophic status determined by the overall content of nutrients (in this case P) in the water column. In oligomictic lakes the potential and the apparent trophic status tend to coincide during circulation events (Fig. 6b). In contrast, in meromictic lakes the observed trophic status is always lower than that implied by the overall nutrient content. In short, the apparent trophic status of a deep lake is under the control both of anthropogenic pressure and climatic evolution. The apparent and the potential trophic status coincide only in the case of constant holomixis and/or homogenisation of the water column.

The extent of the overturn - and the consequent degree of homogenisation of the lacustrine water masses has far-reaching consequences for the determination of the actual renewal times. In oligomictic and meromictic deep lakes it is important to distinguish the renewal time of the deep waters (which may undergo periodic renewal or may be continually separated from the superficial waters) from that of the overlying mixed waters. The assessment of theoretical renewal times (estimated from the volume of the lake divided by that of the outflow) would constitute, if evaluated uncritically, a confusing and misleading element in interpreting the interannual variations of the apparent trophic status in deep lakes.

\section{ACKNOWLEDGMENTS}

From August to December 2001 the chemical analyses for Lake Garda were carried out at the Faculty of
Engineering of the University of Padova (Dr Marco Carrer). The limnological research in Lake Garda was partially funded by the Veneto Region and ARPAV (Veneto Region Environment Protection Agency).

\section{REFERENCES}

Ambrosetti, W., L. Barbanti \& A. Rolla. 1983. La dinamica del mescolamento nei laghi profondi sudalpini. In: W. Ambrosetti, L. Barbanti, R. Mosello, A. Rolla \& D. Ruggiu (Eds), Mescolamento, caratteristiche chimiche, fitoplancton e situazione trofica nei laghi profondi sudalpini. Collana P.F. Promozione della qualità dell'ambiente. CNR $\mathrm{AQ} / 2 / 20: 43-70$.

Brizzio, M.C., L. Garibaldi, B. Leoni \& R. Mosello. 2001. La stabilizzazione della stratificazione chimica del Lago di Iseo e le sue implicazioni sulle caratteriostiche biologiche. Atti Associazione Italiana Oceanologia e Limnologia, 14: 125-136.

Brunetti, M., M. Maugeri \& T. Nanni. 2000. Variations of temperature and precipitation in Italy from 1866 to 1995. Theor. Appl. Climatol., 65:165-174.

Decet F. \& N. Salmaso. 1997. Indagini preliminari sulle caratteristiche chimiche dei principali affluenti e dell'emissario del Lago di Garda. Acqua Aria, 97(7): 91-97.

Garibaldi, L., A. Anzani, A. Marieni, B. Leoni \& R. Mosello. 2003. Studies on the phytoplankton of the deep subalpine Lake Iseo. J. Limnol.: (in press).

Garibaldi, L., M.C. Brizzio, A. Varallo \& R. Mosello. 2000. Eutrofizzazione e meromissi. La situazione dei laghi Iseo e Idro. Atti della Giornata di Studio: I Laghi come Risorsa per lo Sviluppo. Milano, 16 ottobre 1998. Politecnico di Milano, Consiglio Regionale della Lombardia, CNR-III Pallanza e Associazione ex Consiglieri Regionali della Lombardia: 127-142.

Garibaldi, L., M.C. Brizzio, V. Mezzanotte, A. Varallo \& R. Mosello. 1995. The continuing evolution of Lake Iseo (N. Italy): the appearance of anoxia. Mem. Ist. ital. Idrobiol., 53: 191-212. 
Garibaldi, L., M.C. Brizzio, V. Mezzanotte, A. Varallo \& R. Mosello. 1997. Evoluzione idrochimica e trofica del Lago d'Iseo. Documenta Ist. ital. Idrobiol., 61: 135-151.

Garibaldi, L., V. Mezzanotte, M.C. Brizzio, A. Varallo \& R. Mosello. 1998. Apporti di fosforo al Sebino. Confronto fra misure sperimentali e teoriche. Acqua Aria, 98(9): 105-110.

Garibaldi, L., V. Mezzanotte, M.C. Brizzio, M. Rogora \& R. Mosello. 1999. The trophic evolution of Lake Iseo as related to its holomixis. J. Limnol., 58(1): 10-19.

Giugliacci, M., S. Abelli \& G. Dipierro. 2001. Il clima dell'Italia nell'ultimo ventennio. Alpha Test, Milano: 343 pp.

Goldman, C.R. \& A. Jassby. 1990. Spring mixing depth as a determinant of annual primary production in lakes. In: M.M. Tilzer \& C. Serruya (Eds), Large lakes. Ecological structure and function. Springer-Verlag: 125-132.

Hutchinson, G.E. 1957. A Treatise on Limnology. Vol. 1. Geography, Physics and Chemistry. John Wiley and Sons, Inc., New York; Chapman and Hall, Ltd., London: 1015 pp.

IRSA. 1974. Indagini sul Lago di Garda. IRSA Quaderni 18, Roma: $540 \mathrm{pp}$.

Lorenzen, C.J. 1967. Determination of Chlorophyll and PheoPigments: spectrophotometric equations. Limnol. Oceanogr., 12: 343-346.

Maugeri, M \& E. Mazzucchelli. 2002. Il riscaldamento del nostro pianeta: la situazione italiana. Cooperativa Universitaria Studio e Lavoro, Milano: $107 \mathrm{pp}$.

Mosello, R. 1983. Caratteristiche chimiche dei laghi profondi sudalpini. In: W. Ambrosetti, L. Barbanti, R. Mosello, A. Rolla \& D. Ruggiu (Eds), Mescolamento, caratteristiche chimiche, fitoplancton e situazione trofica nei laghi profondi sudalpini. Collana P.F. Promozione della qualità dell'ambiente. CNR AQ/2/20: 71-104.

Mosello, R. \& N. Salmaso. 2000. Cooperazione per lo studio della qualità delle acque dei laghi profondi sudalpini (QuAlps): obiettivi e primi risultati. Atti della Giornata di Studio: I Laghi come Risorsa per lo Sviluppo. Milano, 16 ottobre 1998. Politecnico di Milano, Consiglio Regionale della Lombardia, CNR-III Pallanza e Associazione ex Consiglieri Regionali della Lombardia: 39-50.
Mosello, R., A. Calderoni \& R. de Bernardi. 1997. Le indagini sulla evoluzione dei laghi profondi sudalpini svolte dal CNR Istituto italiano di Idrobiologia. Documenta Ist. ital. Idrobiol., 61: 19-32.

Mosello, R., M. Bianchi, H. Geiss, A. Marchetto, G. Serrini, G. Serrini Lanza, G.A. Tartari \& H. Muntau. 1995. AQUACON-MedBas Subproject 6. Acid rain analysis. Intercomparison 1/94. Documenta Ist. Ital. Idrobiol., 54: $44 \mathrm{pp}$.

OECD. 1982. Eutrophication of waters. Monitoring, assessment and control. OECD, Paris: $154 \mathrm{pp}$.

Salmaso, N. 2002. Ecological patterns of phytoplankton assemblages in Lake Garda: seasonal, spatial and historical features. J. Limnol., 61: 95-115.

Salmaso, N. \& F. Decet. 1998. Interactions of physical, chemical and biological processes affecting the seasonality of mineral composition and nutrient cycling in the water column of a deep subalpine lake (Lake Garda, Northern Italy). Arch. Hydrobiol., 142: 385-414.

Salmaso, N., F. Decet \& P. Cordella. 2002. Spring mixing depth affects the interannual variations in phytoplankton abundance and composition in deep lakes. A case study from Lake Garda (Northern Italy). Verh. int. Ver. Limnol. 28: 1486-1489.

Salmaso, N., F. Decet \& R. Mosello. 1997. Chemical characteristics and trophic evolution of the deep subalpine Lake Garda (Northern Italy). Mem. Ist. ital. Idrobiol., 56: 51-76.

Salmaso, N., F. Decet, G. Franzini \& P. Cordella. 2001a. Evoluzione trofica del Lago di Garda in relazione alla completa circolazione delle acque del 1999 e 2000. Atti Associazione Italiana Oceanologia e Limnologia, 14: 109-123.

Salmaso, N., G. Franzini \& P. Cordella. 2001b. Evoluzione pluriennale delle caratteristiche chimiche e del fitoplancton nel Lago di Garda. Congresso Nazionale della Società Italiana di Ecologia. Atti 25, versione CD-ROM, ISSN 1127-5006: $14 \mathrm{pp}$

Wetzel, R.G. 2001. Limnology. Lake and river ecosystems. $3^{\text {rd }}$ ed., Academic Press, San Diego: 1006 pp. 